Malaysian Journal of Microbiology Vol 4(1) 2008, pp. 40-43

http://dx.doi.org/10.21161/mjm.02008

\title{
Control of root-rot diseases of Phaseolus vulgaris using gliotoxin
}

\author{
Aliaa, R. El-Shami \\ Chemistry of Natural and Microbial Products Dept., NRC, El-Bohoos - Street, Cairo, Egypt \\ E-mail: erhamed@yahoo.com
}

\begin{abstract}
Effect of the antifungal antibiotic gliotoxin on root-rot diseases caused by Fusarium solani and its influence on population of fungal flora in soil were investigated. Bean seeds were treated with different concentrations of gliotoxin before sowing. The results obtained from the green house application of bioagent indicated that soaking seeds in different concentrations of gliotoxin from $1 \mu \mathrm{g} / \mathrm{mL}$ to $15 \mu \mathrm{g} / \mathrm{mL}$ (for 60 minutes) significantly reduced the percentage of damping off and root rot as compared with control (pathogen only). Also $10 \mu \mathrm{g} / \mathrm{mL}$ of gliotoxin was significantly decreased the population of fungal flora as compared with control.
\end{abstract}

Keywords: Biocontrol, Fusarium solani, Gliotoxin, Population of Fungal flora

\section{INTRODUCTION}

Root-rot diseases caused by soil-borne fungi are the most important diseases of many crops. Several fungi were recorded as a causal pathogens of root-rot and wilt diseases such as Rhizoctonia solani, Fusarium solani (Abdallah, 1969; Abou-zeid et al., 1990 and Abou-zeid et al., 1997).

Fusarium wilt disease caused by pathogenic forma specials of the soil inhabiting fungus fusarium, Fusarium oxysporum can cause severe loses in a wide variety of crop plants (Larkin and Fravel, 1998).

Schroth and Cook (1963) tested three bean varities for variation in susceptibility to pre-emergence damping off caused by Rhizoctonia solani, Fusarium solani, and Pythium spp, for amount of seed exudation and suggested that exudates influence the incidence of preemergence damping off by providing fungi with nutritive substances necessary for germination and growth in soil.

Gliotoxin is a potent crystalline antibiotic was produced during the growth of the imperfect fungus Gliocladum fimbriatum (Johnson et al., 1943). Production of the antifungal antibiotics gliotoxin has been associated with its efficacy as a biocontrol agent of soil borne diseases (Howell and Stipanovic, 1995).

Gliotoxin is an immuno-suppressive cytotoxin produced by pathogenic fungal species for this reason. It is one of the mycotoxins which must be systematically searched for biological control (Grovel et al., 2006).

Osamu et al. (2006) stated that fungal secondary metabolites such as gliotoxin were produced by different types of fungi such as Aspergillus, Fusarium and Trichoderma. This work aimed to study the effect of different concentrations of gliotoxin on root-rot diseases, fungal population and determination the optimum concentration for controlling root-rot diseases in phaseolus vulgaris plant.

\section{Corresponding author}

\section{MATERIAL AND METHODS}

\section{Fungal strains}

Aspergillus fumigatus Fersenius NRC (147) and Fusarium solani (Mart.) Sacc NRC (215) were obtained from NRC Microbial collection unit.

\section{Media and growth conditions}

The antifungal antibiotic gliotoxin was produced by A.fumigatus NRC147 strain in a fermentation medium under culture conditions adopted by El-Shami. (2001). Isolation, purification and crystalisation of the compound also have been described.

Different concentrations of the toxin were prepared $(1,5,10$, and $15 \mu \mathrm{g} / \mathrm{mL}$ ethyl alcohol).

\section{In vitro studies}

The antimicrobial activities of gliotoxin against Fsarium solani (pathogenic fungus) was roughly estimated by filter paper disc method (Murray et al., 1995) using an inoculum containing $10^{6}$ fungal cells $/ \mathrm{mL}$ distilled water spread on Czapek Dox Agar ( $0.25 \mathrm{~mL}$ inoculum/plate) Four sets of filter paper disks $5 \mathrm{~mm}$ in diameter were saturated with the different concentrations of gliotoxin (1. 5,10 and $15 \mu \mathrm{g} / \mathrm{mL}$ ). Another set of discs were soaked in ethyl alcohol to serve as control. The prepared discs were dried and firmly applied to the surface of Czapek Dox Agar plates inoculated with the pathogenic fungus. Then the plates were incubated at $28-30{ }^{\circ} \mathrm{C}$ for $48-72 \mathrm{~h}$. Diameters of inhibition zones were measured in $\mathrm{mm}$. 


\section{In situ studies}

Pot experiments were carried out in the green house of the National Research Centre (N.R.C), Dokki, Cairo to study the activity of gliotoxin in suppressing the pathogenic fungus (Fusarium solani) the causal agent of wilt and / or root rot of bean seedlings. Seeds of Phaseolus vulgaris abtained from the Agricultural Research Centre in Giza were used. Seeds were surface sterilized using $0.5 \% \mathrm{w} / \mathrm{v}$ sodium hypochloride $(\mathrm{NaOCl})$ for $5 \mathrm{~min}$ and washed 3 times by sterilized distilled water, then soaked in four concentrations of gliotoxin 1, 5, 10, $15 \mu \mathrm{g} / \mathrm{mL} 60 \mathrm{~min}$. Another group of seeds were soaked in sterilized distilled water served as control. The experiment was done and evaluated by Hamed (2001).

The effect of the antibiotic gliotoxin on root rot and wilt disease was evaluated under green house conditions during seedling stage after 15 days from sowing and on plant maturity after 45 days.

\section{Population of fungal flora in soil}

The effective concentration of gliotoxin was found to be $10 \mu \mathrm{g} / \mathrm{mL}$. The pot experiments were repeated using unsterilized soil and treated with $3 \%$ wheat meal-sand medium (WSM) inoculated with the pathogen and seeds soaked in $10 \mu \mathrm{g} / \mathrm{mL}$ gliotoxin. Another three replicates of pots served as control (seeds were soaked in distilled water). Population of fungal flora in soil were estimated after six weeks from planting. Soil suspensions were prepared by mixing $10 \mathrm{gm}$ of soil with $90 \mathrm{ml}$ sterile water. The soil water was subjected to serial dilution $\left(10^{-2}, 10^{-3}\right.$, $10^{-4}, 10^{-5}$ ) . Three replicate plates were prepared from each concentration. One $\mathrm{mL}$ of each sample was poured into sterilized plates and $20 \mathrm{~mL}$ sterilized medium (Czapek-Dox-Agar) previously prepared. The same steps were done to the control soil. The plates were incubated at $28^{\circ} \mathrm{C}$ and fungal count was estimated after 5 days and again after 8 days to count the slow growing fungal species. The isolated fungi were identified in the National Research Center, Chemistry of Natural and Microbial Products Dept. Microbial Culture Collection Unit (MCCU) according to their morphological characters (Barent, 1960). The results were statistical analyzed using Co. Stat. Progrm, Software. One way analysis was made and the treatments mean were compared by LSD at 5 and $1 \%$ probability (Snedecor and Cochrou, 1990).

\section{RESULTS AND DISCUSSION}

The results in vitro showed that the different concentrations of gliotoxin had strong antimicrobial activities against $F$. solani. In general, concentration 10 $\mu \mathrm{g} / \mathrm{mL}$ was sufficient to stop the growth of the tested organism as shown in Table 1 and Figure 1.

This result was in agreement with Johnson et al. (1943), Boutibonnes et al. (1984), and El-Shami (2001) lend a strong support that gliotoxin exhibited strong antimicrobial potentialities aganist gram negative bacteria, gram positive bacteria, yeast and filamentous fungi.

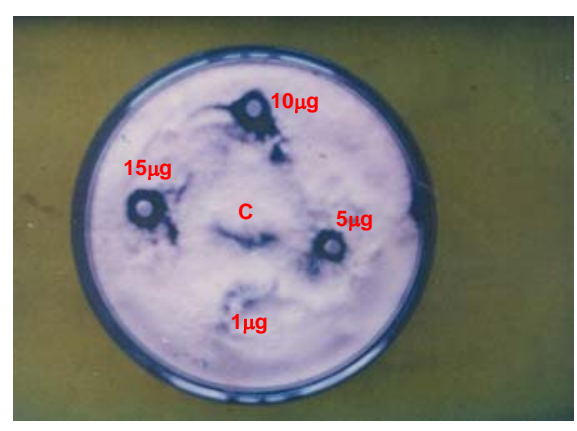

Figure 1: Antimicrobial activities of different concentrations of gliotoxin on F. solani

(C) Control

(1) Gliotoxin $1 \mu \mathrm{g} / \mathrm{mL}$

(2) Gliotoxin $5 \mu \mathrm{g} / \mathrm{mL}$

(3) Gliotoxin $10 \mu \mathrm{g} / \mathrm{mL}$

(4) Gliotoxin $15 \mu \mathrm{g} / \mathrm{mL}$

Table 1: Antimicrobial activities of gliotoxin against Fusarium solani

\begin{tabular}{cc}
\hline $\begin{array}{c}\text { Concentration of gliotoxin } \\
(\boldsymbol{\mu g} / \mathbf{m L})\end{array}$ & $\begin{array}{c}\text { Inhibition zone } \\
(\mathbf{m m})\end{array}$ \\
\hline Control & 0 \\
1 & 0 \\
5 & 8 \\
10 & 10 \\
15 & 12 \\
L.S.D. $5 \%$ & 2.82 \\
L.S.D. $1 \%$ & 4.01 \\
\hline
\end{tabular}

From the results in Table 2, it is obvious that increasing the gliotoxin concentration until $10 \mu \mathrm{g} / \mathrm{mL}$ reduced the percentage of damping-off and wilt as compared with the control (untreated seeds).

Highly reduction in infection with pre-emergence damping off and root-rot disease of bean plants was observed when treated seeds with $10 \mu \mathrm{g} / \mathrm{ml}$ gliotoxin were cultivated in F. solani infected soil. Gliotoxin is likely to be responsible for biocontrol activity in vivo (Brian and Hemming, 1975). The continuous increase in gliotoxin up to $15 \mu \mathrm{g} / \mathrm{mL}$ leads to increasing the percentage of damping off and wilt another time this result might be reflectance of the toxic effect of gliotoxin on bean seeds. The result coincided with Haraguchi et al. (1995) who said that gliotoxin, inhibited tobacco cell growth by inhibiting acetolactate synthtase activity which is the first step in the biosynthesis of branched chain amino acids in cultured tobacco cells.

Gliotoxin was found to be active against Rhizoctonia bataticola (0.03 mu g ml (-1)), Macrophomina phaseolina (1.76 mu g ml (-1)), Pythium debaryanum (29.38 mu g ml (-1)), Pythium aphanidermatum (12.02 mu g $\mathrm{ml}(-1)$ ), Sclerotium rolfsii (2.11 mu g $\mathrm{ml}(-1)$ ), Rhizoctonia solani (3.18 mu g ml (-1)) [Singh-shyamli et al., 2005). 
The results in Table 3 shows a significant decrease in the population of fungi when the soil was treated with $10 \mu \mathrm{g} / \mathrm{mL}$ gliotoxin after 6 weeks of planting.

Table 2: In situ effect of gliotoxin against Fusarium solani on bean plant during seedling stage

\begin{tabular}{ccc}
\hline Treatment & \% Dumping off & \% root-rot \\
\hline $1 \mu \mathrm{g} / \mathrm{mL}$ & 76 & 54.5 \\
$5 \mu \mathrm{g} / \mathrm{mL}$ & 47.6 & 40 \\
$10 \mu \mathrm{g} / \mathrm{mL}$ & 23.8 & 12.5 \\
$15 \mu \mathrm{g} / \mathrm{mL}$ & 47.1 & 33.3 \\
Control & & \\
(untreated & 90.5 & 100 \\
seeds) & & \\
L.S.D. 5\% & 4.86 & 5.33 \\
L.S.D. 1\% & 6.92 & 7.59 \\
\hline
\end{tabular}

Table 3: Fungal population in soil for control and treated seeds with $10 \mu \mathrm{g} / \mathrm{mL}$ gliotoxin

\begin{tabular}{ccc}
\hline Species isolated & Control & Treated \\
\hline Alternaria & & \\
A. dianthi & + & - \\
Aspergillus & & \\
A. flavipes & ++ & + \\
A. fumigatus & + & + \\
A. niger & +++ & + \\
A. usfus & + & + \\
A. versicolor & + & + \\
Cephalosporium & & \\
C. acremonium & + & + \\
Fusarium & & \\
F. oxysporum & ++ & + \\
F. solani & +++ & + \\
Penicillium & & \\
P. citrinum & + & - \\
P. notatum & +++ & + \\
P. stoloniferum & + & + \\
\hline
\end{tabular}

$$
\begin{array}{ll}
\text {-ve } & \left(\mathrm{N}^{\circ} \text { of cells }=0\right) \\
\text { +ve } & \left(\mathrm{N}^{\circ} \text { of cells }=1 \times 10^{4}: 2 \times 10^{4}\right) \\
++\mathrm{ve} & \left(\mathrm{N}^{\circ} \text { of cells }=3 \times 10^{4}\right) \\
+++\mathrm{ve} & \left(\mathrm{N}^{\circ} \text { of cells }>4 \times 10^{4}\right)
\end{array}
$$

Gliocladium virens and $A$. fumigatus are filamentous fungi formulated for the bilogical control of damping off diseases of plants seed parts of its antagonistic activity. It is due to the production of an epidithiodioxy-piperazine antibiotic (gliotoxin) (Wilhite and Straney, 1996).

Production of the antifungal antibiotic gliotoxin by the biocontrol fungus G.virens has been associated with its efficacy as a biocontrol agent of seedling diseases infected by R.solani, Fusarium solani and Pithium ultimum (Howell and Stipanovic, 1995).

The antifungal activity of some compounds is due to their ability to affect the function or the structure of the plasmalema and other membranes of the fungal cell. These compounds often indicated as antibiotics, may include small molecules and peptides, proteins, enzymes and chemicals pesticides. Cell wall degrading enzymes and cell membrane degrading enzymes produced by plants, bacteria and fungi are also powerful antifungal agents in vitro (Mauch et al., 1988; Lorito et al., 1994; Lorito et al., 1993). Some active compounds cell membrane and cell wall degrading enzymes are able to interact synergistically in the inhibition of pathogenic fungi and it has been suggested that this synergism is involved in both plant defense and microbial biocontrol mechanisms (Schirmbok et al., 1994).

Gliotoxin, which selectively attacks thiol groups located on cell membranes (Johnes and Hancock, 1988), and may be strongly enhance the fungicidal effect of commonly used inhibitors of sterol synthesis, which alter membrane integrity and structure (Lorito et al., 1994).

\section{REFERENCES}

Abdallah, A.M.A. (1969) Studies on root diseases of broad bean in Egypt. M.Sc. Thesis, Fac. Agric., Ain Shams Univ.

Abouzeid, N.M., El-Waki, A.A., El-Sherif, I.M. and Amer, M.I. (1990) Studies on root-rot and wilt of lentil and their control. Agric. Res. Pesriew 68, 421429.

Abouzeid, N.M., El-Morsy, G.A. and Hassanein, A.M. (1997) Major organisms causing root rot/ wilt and their relative importance on fababean, lentil and chickpea. Egypt. J. Agric. Res. 25, 529-542.

Barnet H.L. (1960). Illustrated Genera of Imperfect Fungi $2^{\text {nd }}$ Ed., Bulgess Publishing Company.

Boutibonnes, P., Auffrary, Y, Malherbe, C., Kogho, W. and Marais, C. (1984) Properties antibacteriennes et genotosciques de 33 mycotoxines. Mycopatholagia 87: 43-49.

Brian, P.W. and Hemming, H.G. (1975) Gliotoxin a fungistatic metabolic product of Trichoderma virens. Annals of Applied Biology 32: 214-224.

EI Shami, A.R. (2001) Biochemical studies on the production of some pharmaceutical compounds by Aspergillus fumigatus. Ph. D. Thesis. Faculty of Science, Mansoura University.

Grovel, O., Kerzaon, I., Petit, K., Du Pont, T.E and Pouchus, Y. (2006) A new and rapid bioassay for the detection of gliotoxin and related epipolythiodioxopiperazines produced by fungi. Journal of Microbiological Methods 66: 286-293.

Hamed, E.R. (2001) The effect of secondary metabolites of some fungi on the growth of wilt and root-rot fungi. Ph. D. Thesis, Faculty of Agric. Cairo University.

Haraguchi, H., Y, Hamada, M, and Tachivo, A (1995) Effect of Gliotoxin on growth and branched chain amino acid biosynthesis in plants. Phytochemistry 42: 645-648.

Howell, C.R. and Stipanovic, R.D. (1995) Mechanisms in the biocontrol of Rhizoctonia solani indused cotton seedling disease by Gliocladium virens: antibiosis. Phytopathol 85: 469-472. 
Johnson, J. R., Bruce, W.F. and ditcher, J.D. (1943)

Gliotoxin, the antibiotic principle of Gliocladium fimbriatum I production, physical and biological properties. Journal of the American Chemical Society 65: 2005-2009.

Jones, R.W., and Hancock, J. G. (1988) Mechanism of gliotoxin action and factors mediating gliotoxin sensitivity. Journal of General Microbiology 134: 2067-2075.

Larkin, R.R. and Fravel, D. R. (1998) Efficiency of various fungal and bacterial biocontrol organisms for control of fusarium wilt of tomato. Plant Diseases 82: 1022-1028.

Lorito, M., Di Pietro, A., Hayes, C.K., Woo, S.L., and Harman, G.E. (1993) Antifungal, synergistic interaction between chitinolytic enzymes from Trichoderma harzianum and Enterobacter closcae. Pytopathol 83: 721-728.

Lorito, M., Leterbauer, C., Hayes, C.K., Woo, S.L. and Harman, G.E. (1994) Synergistic combination of cell wall degrading enzymes and different antifungal compounds enhances inhibition of spore germination. Microbiology (London) 140: 623-629.

Mauch, F., Mauch, Mani, B., and Boller, T. (1988) Antifungal hydrolases in pea tissue. II. Inhibition of fungal growth by combinations of chitinase and B-1,3 glucanase. Plant Physiology (Lancaster) 88: 936942.

Murray, P,R., Baron, E.J., Pfaller, M.A., Tenover, F.C. and Yolke, R.H. (1995) Manual of clinical. Microbiology,6th ed, ASM, Washington, DC.

Osamu, N, Yoshihiro, S., Tetsuro, Y., Toshio, I. Tadatoshi, T. and Chisei, R. (2006) Fungal metabolite gliotoxin blocks most cell activation by a calcium - and superoxid dependent mechanism: Implications for immunosuppressive activities. Clinical Imamunology 118: 108-116.

Schirmböck, M., Lorito, M., Wang, Y.L., Arisan Atac., I., Scala, F., and Kubicek, C.P. (1994) Parallel formation and synergism of hydrolytic enzymes and peptaidal antibiotics, molecular mechanisms involved in the antagonistic action of Trichoderma harzianum against phytopathogenic fungi. Appl. Environ. Microbial, 60: 9-16.

Schroth, M.N. and Cook, M.J. (1963). Seed exudation and influence on pre-emergence damping-off of been. Phytopathol. 53: 620-623.

Singh, Shyamli., Dureja, Prem, and Tanwar, R.S. (2005) Production and antifungal activity of secondary metabolites of Trichoderma virens Pesticide Research Journal 17(2): 26-29.

Snedecor, G.W. and WG Cochrou (1990). Statistical methods $8^{\text {th }}$ ed lowu state vniu pres Ames, lowu, USA.

Wilhite S.E. and Straney, D.C. (1996). Timing of gliotoxin biosynthesis in the fungal biological control agent Gliocladium virens (trichodenma virens). Applied Microbiology and Biotechnology 45: 513518. 